\title{
DOE Commercial Building Energy Asset Score Web Service (Draft)
}

G Elliott

N Wang

J Almquist

September 2013

Version 1

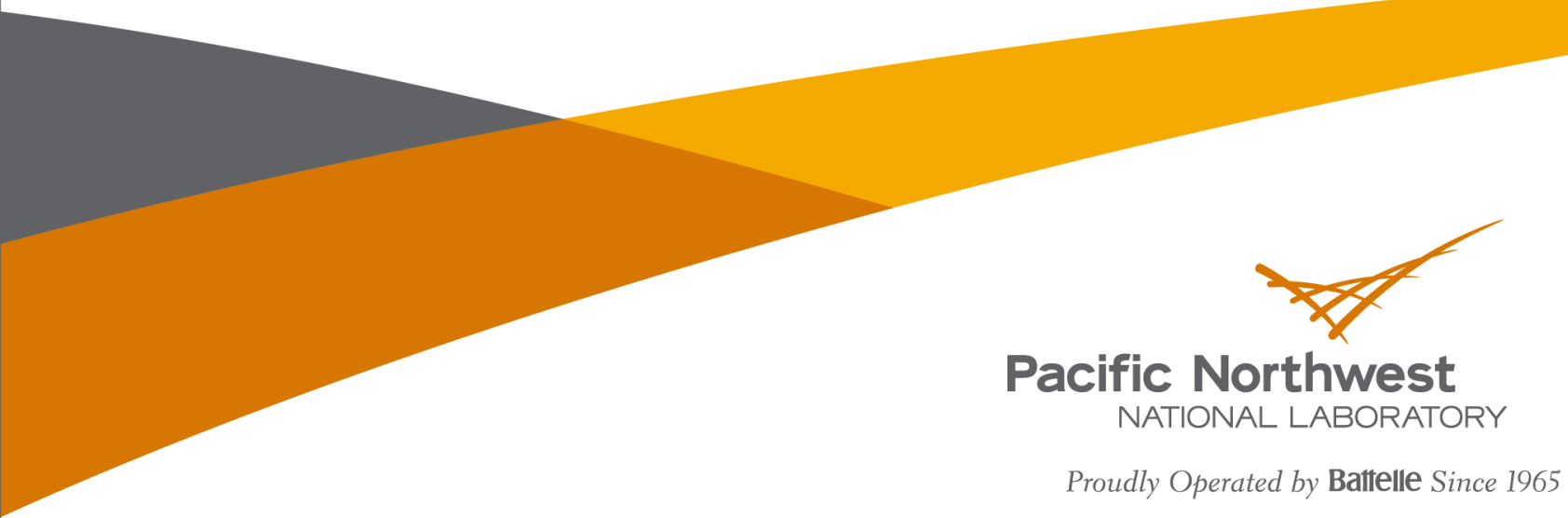




\title{
DISCLAIMER
}

This report was prepared as an account of work sponsored by an agency of the United States Government. Neither the United States Government nor any agency thereof, nor Battelle Memorial Institute, nor any of their employees, makes any warranty, express or implied, or assumes any legal liability or responsibility for the accuracy, completeness, or usefulness of any information, apparatus, product, or process disclosed, or represents that its use would not infringe privately owned rights. Reference herein to any specific commercial product, process, or service by trade name, trademark, manufacturer, or otherwise does not necessarily constitute or imply its endorsement, recommendation, or favoring by the United States Government or any agency thereof, or Battelle Memorial Institute. The views and opinions of authors expressed herein do not necessarily state or reflect those of the United States Government or any agency thereof.

\author{
PACIFIC NORTHWEST NATIONAL LABORATORY \\ operated by \\ BATTELLE \\ for the \\ UNITED STATES DEPARTMENT OF ENERGY \\ under Contract DE-AC05-76RL01830 \\ Printed in the United States of America \\ Available to DOE and DOE contractors from the \\ Office of Scientific and Technical Information, \\ P.O. Box 62, Oak Ridge, TN 37831-0062; \\ ph: (865) 576-8401 \\ fax: $(865)$ 576-5728 \\ email: reports@adonis.osti.gov \\ Available to the public from the National Technical Information Service \\ 5301 Shawnee Rd., Alexandria, VA 22312 \\ ph: (800) 553-NTIS (6847) \\ email: orders@ntis.gov <http://www.ntis.gov/about/form.aspx> \\ Online ordering: http://www.ntis.gov
}




\section{DOE Commercial Building Energy Asset Score Web Service (Draft)}

G Elliott

N Wang

$\mathrm{J}$ Almquist

September 2013

Prepared for

the U.S. Department of Energy

under Contract DE-AC05-76RL01830

Pacific Northwest National Laboratory

Richland, Washington 99352 



\section{Authors' Note}

This documentation for the Energy Asset Score API is still a work in progress. Feedback is welcome and can be directed to Geoff Elliott (geoff.elliott@pnnl.gov), Justin Almquist (justin.almquist@pnnl.gov) and Nora Wang (na.wang@pnnl.gov). 



\section{Contents}

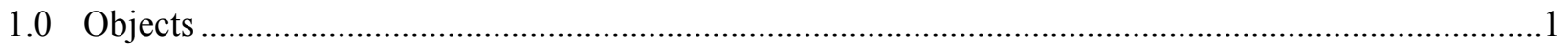

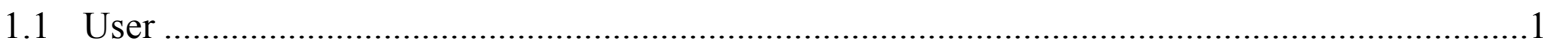

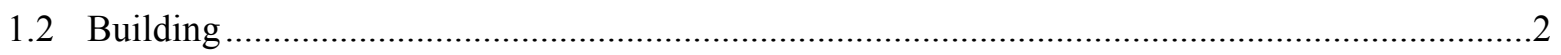

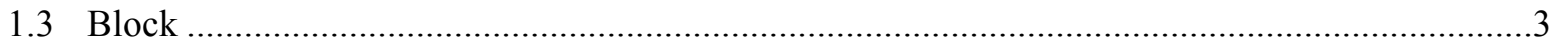

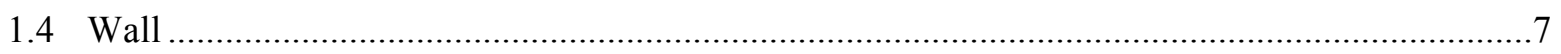

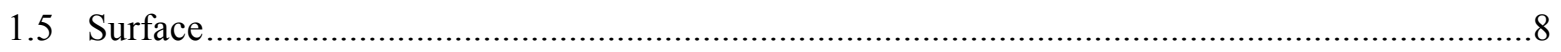

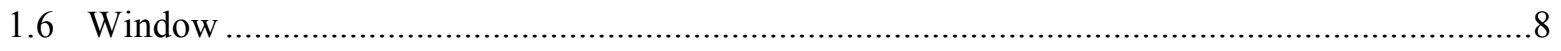

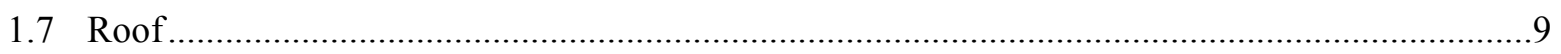

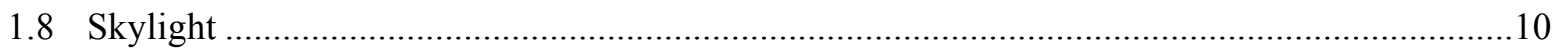

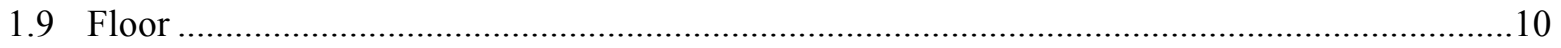

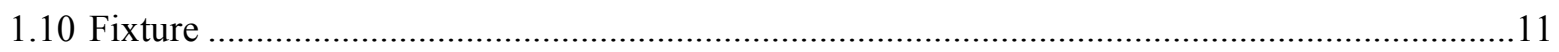

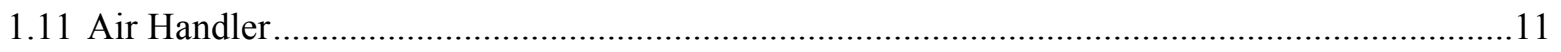

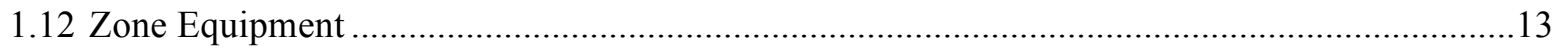

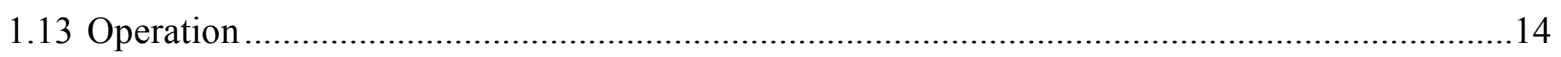

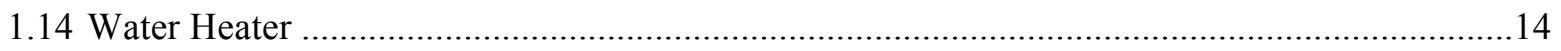

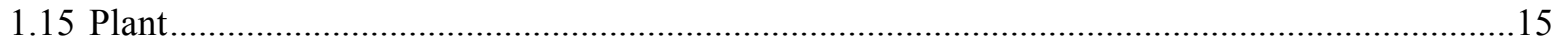

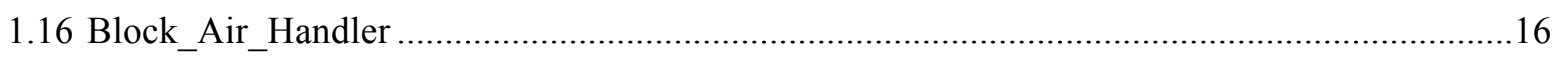

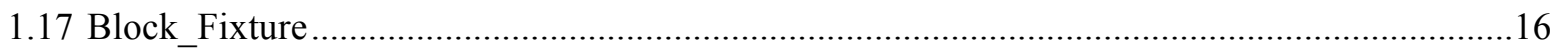

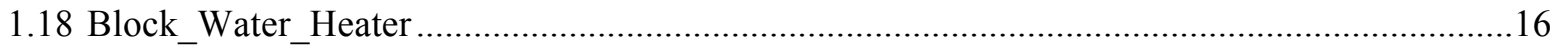

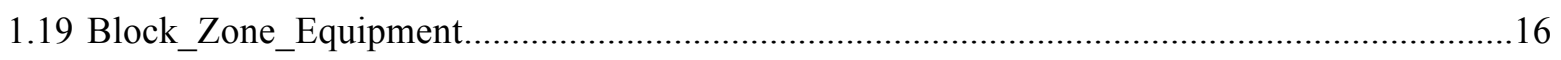

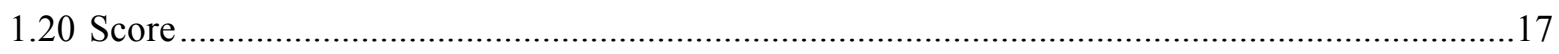




\section{Figures}

Figure 1. Energy Asset Score Application Objects.............................................................................

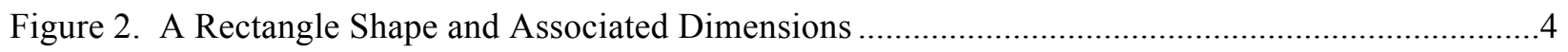

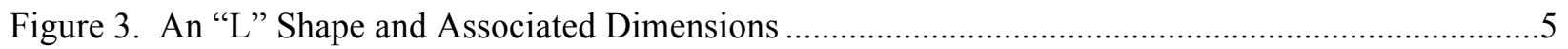

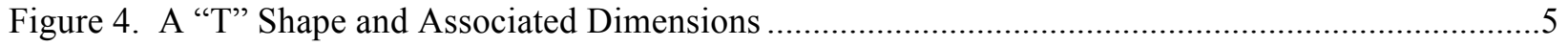

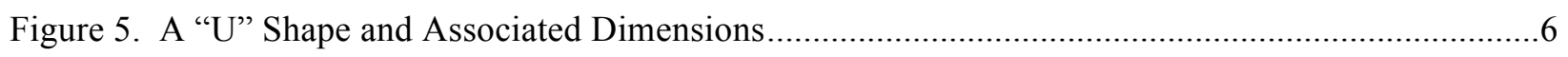

Figure 6. An "H" Shape and Associated Dimensions .........................................................................6

Figure 7. A Courtyard Shape and Associated Dimensions ...................................................................

\section{Tables}

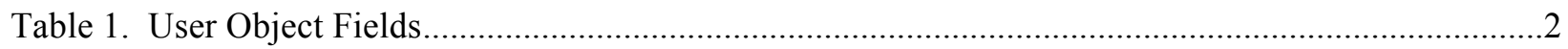

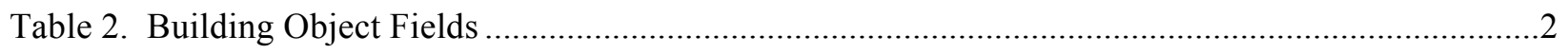

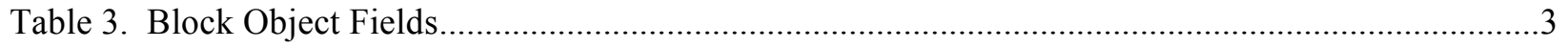

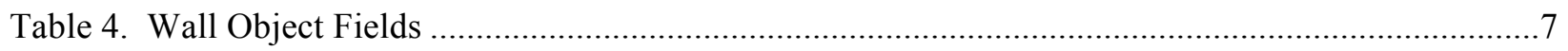

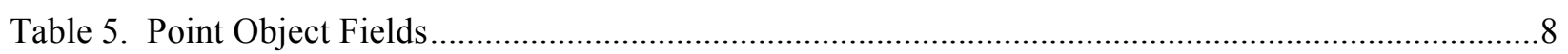

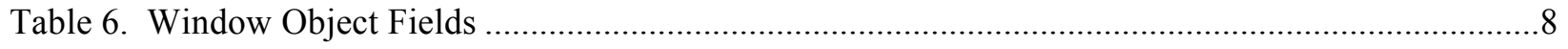

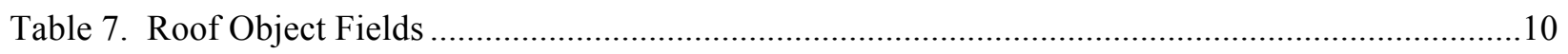

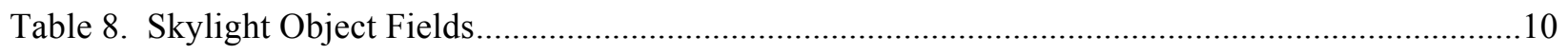

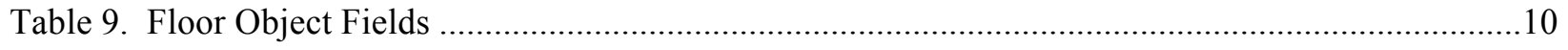

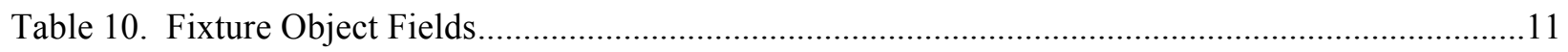

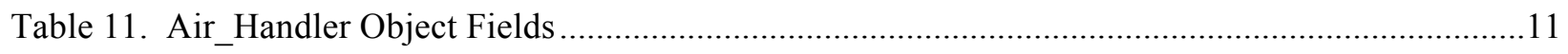

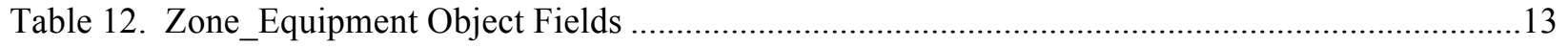

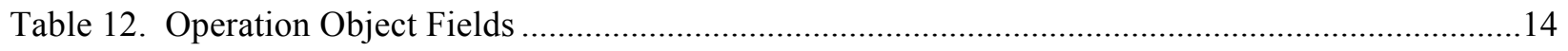

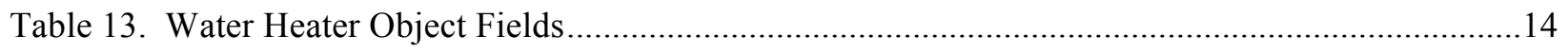

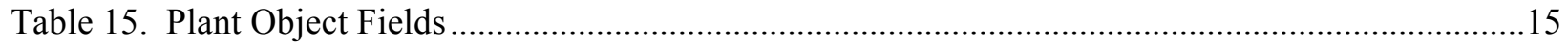

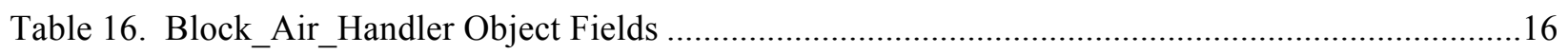

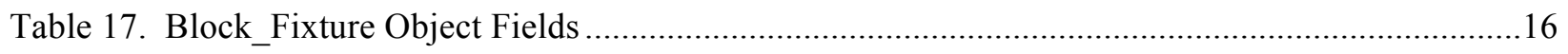

Table 18. Block_Water_Heater Object Fields ...................................................................................16

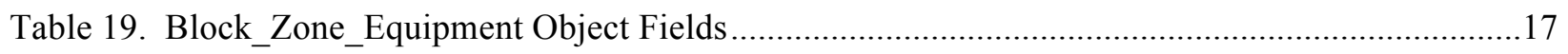

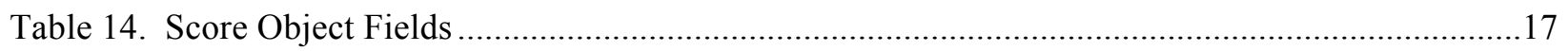




\subsection{Objects}

The central object in the Energy Asset Score application is a Building. Buildings belong to Users. Each Building is composed of one or more Blocks, each of which is the parent of several other objects that contain the definitions of that Block. A Building also holds references to HVAC Systems and Water Heaters. Once a Building has been simulated, it receives a Score object containing the simulation results.

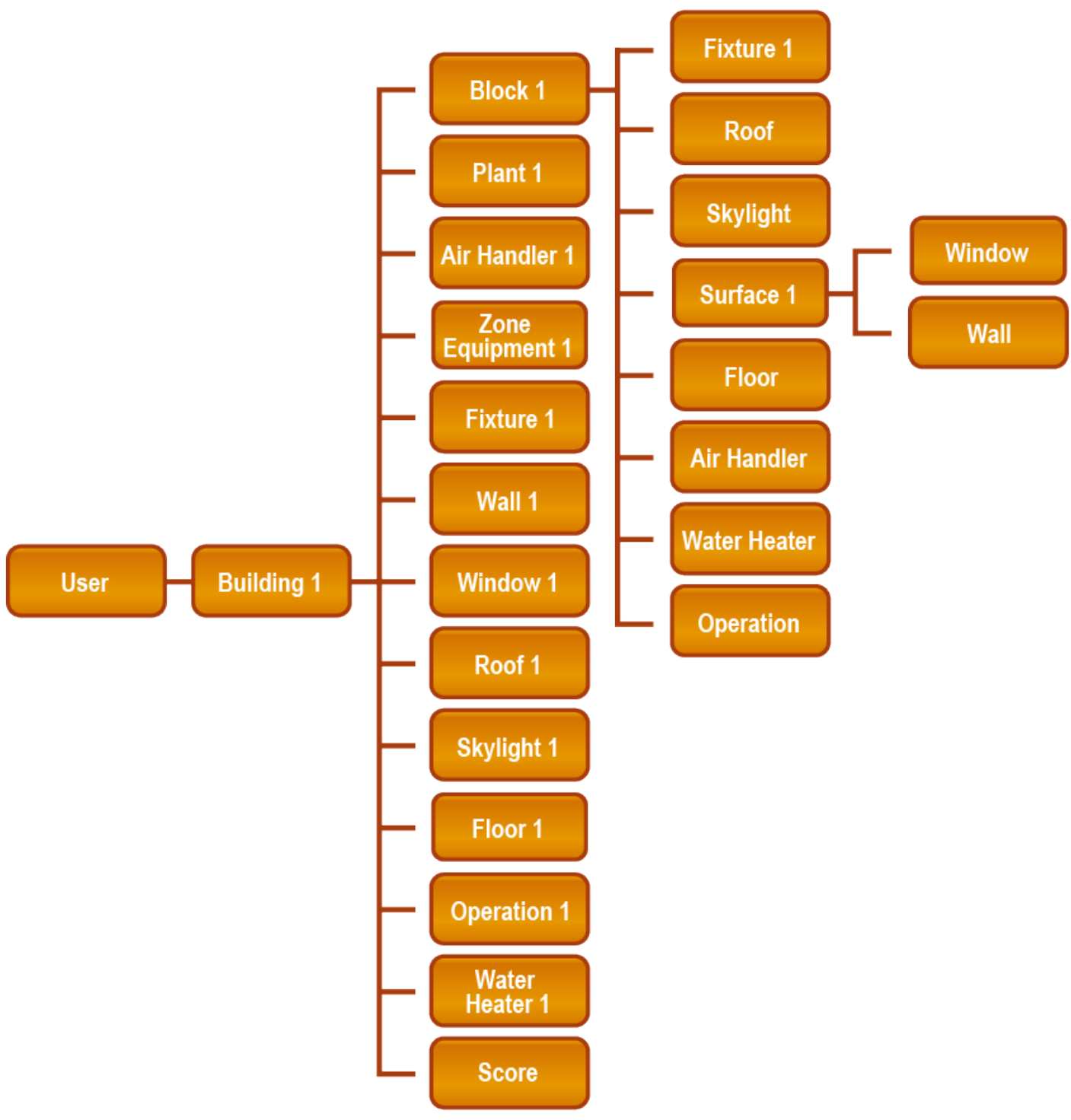

Figure 1. Energy Asset Score Application Objects

\subsection{User}

The User object is created for each unique account within the Energy Asset Score application. Each User has a unique, automatically assigned ID, in addition to a unique email address supplied when the account is created. 
Table 1. User Object Fields

\begin{tabular}{lll}
\hline \multicolumn{1}{c}{ Field } & \multicolumn{1}{c}{ Type } & \multicolumn{1}{c}{ Description } \\
\hline id & $\begin{array}{l}\text { Integer } \\
\text { email }\end{array}$ & $\begin{array}{l}\text { The unique identifier for this user, used in get and update requests. } \\
\text { Email address used for login, resetting passwords, and contacting the user } \\
\text { with simulation results. }\end{array}$ \\
$\begin{array}{l}\text { password } \\
\text { organization_id } \\
\text { created_at }\end{array}$ & $\begin{array}{l}\text { String } \\
\text { Integer } \\
\text { Datetime }\end{array}$ & $\begin{array}{l}\text { Unique identifier for the organization this user belongs. } \\
\text { Date and time the user account was created in the Energy Asset Score } \\
\text { application. }\end{array}$ \\
$\begin{array}{l}\text { updated_at } \\
\text { Date and time the user account was updated in the Energy Asset Score } \\
\text { application. }\end{array}$ \\
\hline
\end{tabular}

\subsection{Building}

Each Building is represented by a unique, automatically assigned ID and a user-supplied name (which doesn't need to be unique). Additionally, the building object holds references to all "assets" that may be later assigned to particular blocks of that building. For instance, the construction informatation such as roofs, walls and windows, as well as fixtures, heating/cooling and operations.

Table 2. Building Object Fields

\begin{tabular}{|c|c|c|}
\hline Field & Type & Description \\
\hline id & Integer & The unique identifier for this building, used in get and update requests. \\
\hline Name & String & $\begin{array}{l}\text { A custom name given to the building. This is displayed in the Energy } \\
\text { Asset Score Report and used in the application as the primary } \\
\text { identification for the building. }\end{array}$ \\
\hline year_of_construction & Integer & The year the building was originally constructed. \\
\hline total_floor_area & Float & $\begin{array}{l}\text { The sum of the floor areas of the spaces within the building, including } \\
\text { basements, mezzanine and intermediate-floored tiers, and penthouses } \\
\text { with a headroom height of } 7.5 \mathrm{ft} \text { or greater. It excludes covered } \\
\text { walkways, open roofed-over areas, porches and similar spaces, pipe } \\
\text { trenches, exterior terraces or steps, chimneys, roof overhangs, and } \\
\text { similar features. }\end{array}$ \\
\hline user_id & Integer & ID of the user who created the building. \\
\hline notes & String & Description of the building. \\
\hline address & String & Street address for the building. \\
\hline city & String & City in which the building is located. \\
\hline state & String & State in which the building is located. \\
\hline zip_code & Integer & Postal code in which the building is located. \\
\hline created_at & Datetime & $\begin{array}{l}\text { Date and time the building was created in the Energy Asset Score } \\
\text { application. }\end{array}$ \\
\hline updated_at & Datetime & $\begin{array}{l}\text { Date and time the building was last updated in the Energy Asset Score } \\
\text { application. }\end{array}$ \\
\hline status_type_id & Integer & $\begin{array}{l}\text { Indicates the current simulation status of the building: } \\
\text { 1. No active score, can be updated } \\
\text { 2. In the simulation queue, unavailable for updates } \\
\text { 3. Has an active score, unavailable for updates }\end{array}$ \\
\hline blocks & Array & An array of Block objects. \\
\hline
\end{tabular}




\begin{tabular}{lll}
\hline \multicolumn{1}{c}{ Field } & Type & Description \\
\hline air_handlers & Array \\
\hline zone_equipment & Array \\
water_heaters & Array \\
\hline use_types & Array \\
\hline roofs & Array & \\
\hline skylights & Array & \\
walls & Array & Array \\
windows & Array \\
floors & Array \\
fixtures & Array \\
plants & Array \\
\hline operations &
\end{tabular}

\subsection{Block}

Blocks are the foundational object of a Building. Each Block contains Roof, Floor, Surface, Mechanical, Water Heater, and Operations objects, as well as one or more Fixture objects.

Table 3. Block Object Fields

\begin{tabular}{|c|c|c|}
\hline Field & Type & Description \\
\hline$\overline{\text { id }}$ & Integer & The unique identifier for this block. \\
\hline name & String & $\begin{array}{l}\text { A custom name given to the block. This name is displayed in the } \\
\text { user interface. }\end{array}$ \\
\hline shape_id & Integer & $\begin{array}{l}\text { ID corresponding to a specific block shape: } \\
\text { 1. Rectangle } \\
\text { 2. Courtyard } \\
\text { 3. H-shape } \\
\text { 4. L-shape } \\
\text { 5. T-shape } \\
\text { 6. U-shape }\end{array}$ \\
\hline dimension_1 & Float & $\begin{array}{l}\text { These dimension values change depending on the shape being used. } \\
\text { See Figure } 2 \text { through Figure } 7 \text {. }\end{array}$ \\
\hline dimension_2 & Float & \\
\hline dimension_3 & Float & \\
\hline dimension_- 4 & Float & \\
\hline dimension_5 & Float & \\
\hline dimension_6 & Float & \\
\hline dimension_7 7 & Float & \\
\hline dimension_8 & Float & \\
\hline dimension_9 & Float & \\
\hline created_at & Datetime & $\begin{array}{l}\text { Date and time the user account was created in the Energy Asset Score } \\
\text { application. }\end{array}$ \\
\hline updated_at & Datetime & $\begin{array}{l}\text { Date and time the user account was updated in the Energy Asset } \\
\text { Score application. }\end{array}$ \\
\hline number_of_floors & Integer & Number of above ground floors included in the block. \\
\hline number_of_bg_floors & Integer & Number of below ground floors included in the block. \\
\hline floor_to_floor_height & Float & Distance between floors, including any drop ceiling space. \\
\hline has_drop_ceiling & Boolean & $\begin{array}{l}\text { Value should be true if the floors within this block include a drop } \\
\text { ceiling. }\end{array}$ \\
\hline floor_to_ceiling_height & Float & Distance between the floor and ceiling, not including any drop ceiling \\
\hline
\end{tabular}




\begin{tabular}{|c|c|c|}
\hline Field & Type & Description \\
\hline & & space. \\
\hline use_type_id & Integer & $\begin{array}{l}\text { ID corresponding to a specific use type: } \\
\text { 1. Assembly } \\
\text { 2. Education } \\
\text { 3. Food Sales } \\
\text { 4. Food Service } \\
\text { 5. Health Care } \\
\text { 6. Lodging } \\
\text { 7. Mercantile and Service } \\
\text { 8. Office } \\
\text { 9. Public Order/Safety } \\
\text { 10. Warehouse, nonrefrigerated } \\
\text { 11. Refrigerated Warehouse } \\
\text { 12. Other }\end{array}$ \\
\hline has_timer_controls & Boolean & $\begin{array}{l}\text { Value should be true if the lighting fixtures within this block have } \\
\text { timer controls. }\end{array}$ \\
\hline surfaces & Array & An array of Surface objects. \\
\hline roof & Object & The Roof definitions for this block. \\
\hline floor & Object & The Floor definitions for this block. \\
\hline fixtures & Array & An array of Fixture objects. \\
\hline air_handlers & Array & The Air Handlers assigned to this block. \\
\hline zone_equipment & Array & The Zone Equipment assigned to this block. \\
\hline operation & Object & The Operation definitions for this block. \\
\hline water_heaters & Array & The Water Heaters assigned to this block. \\
\hline
\end{tabular}

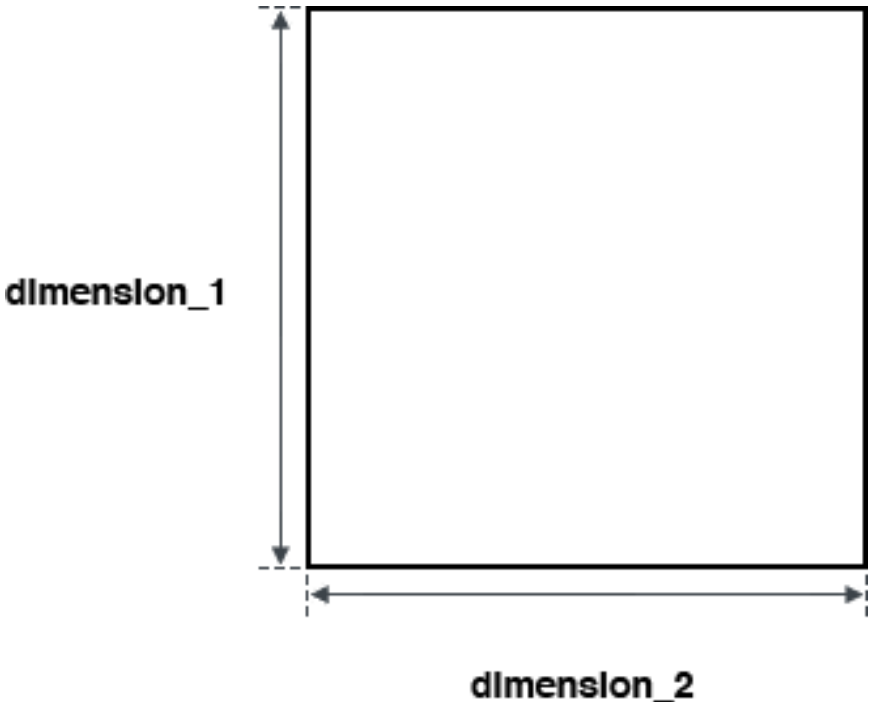

Figure 2. A Rectangle Shape and Associated Dimensions 


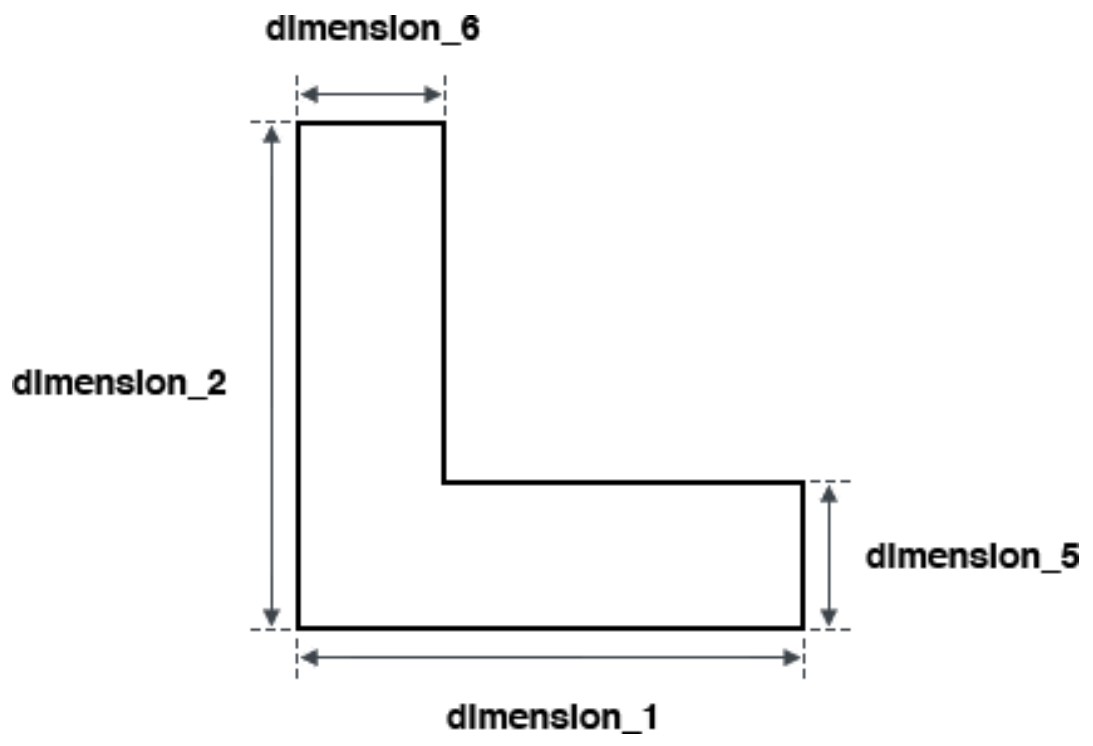

Figure 3. An "L" Shape and Associated Dimensions

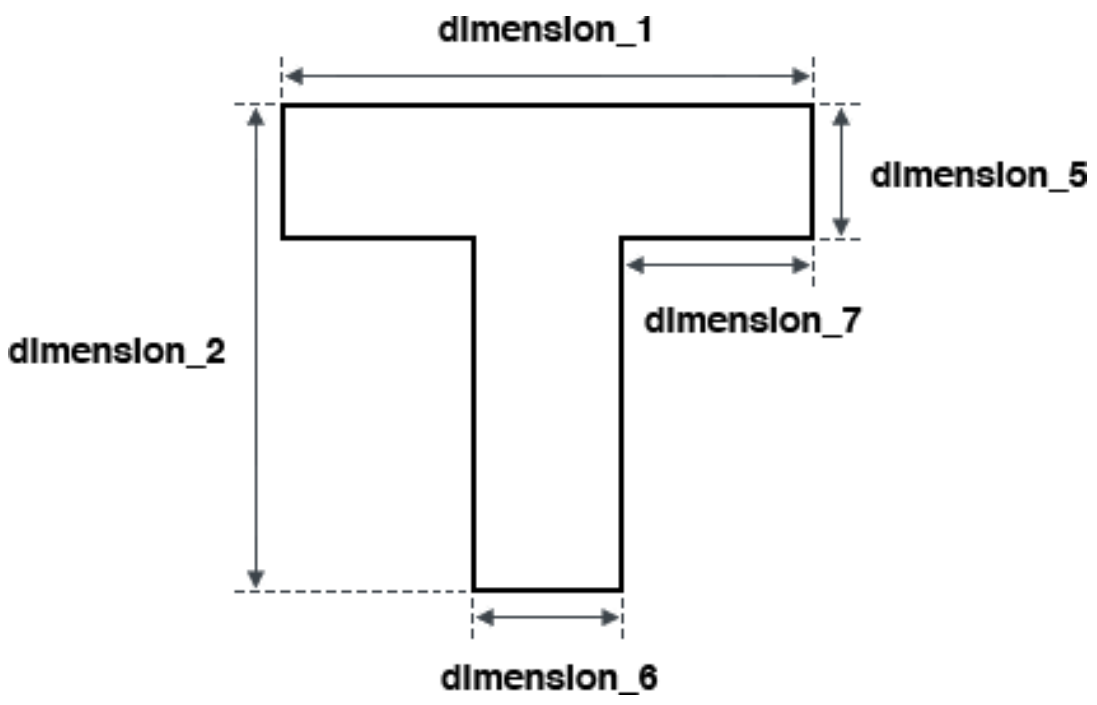

Figure 4. A "T" Shape and Associated Dimensions 


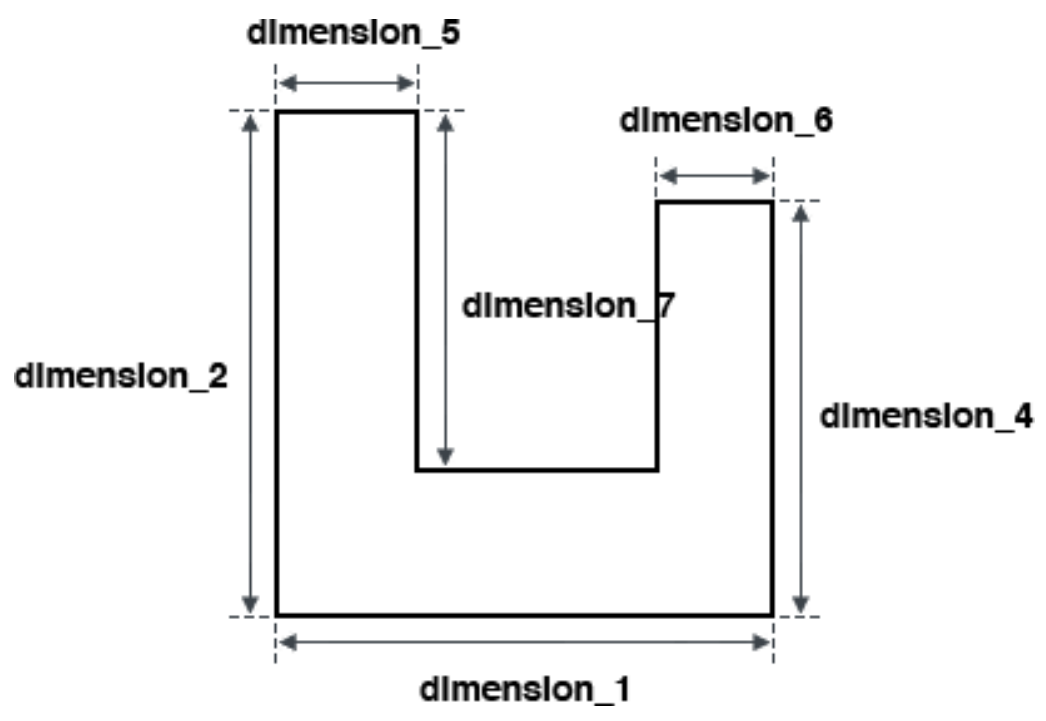

Figure 5. A "U" Shape and Associated Dimensions

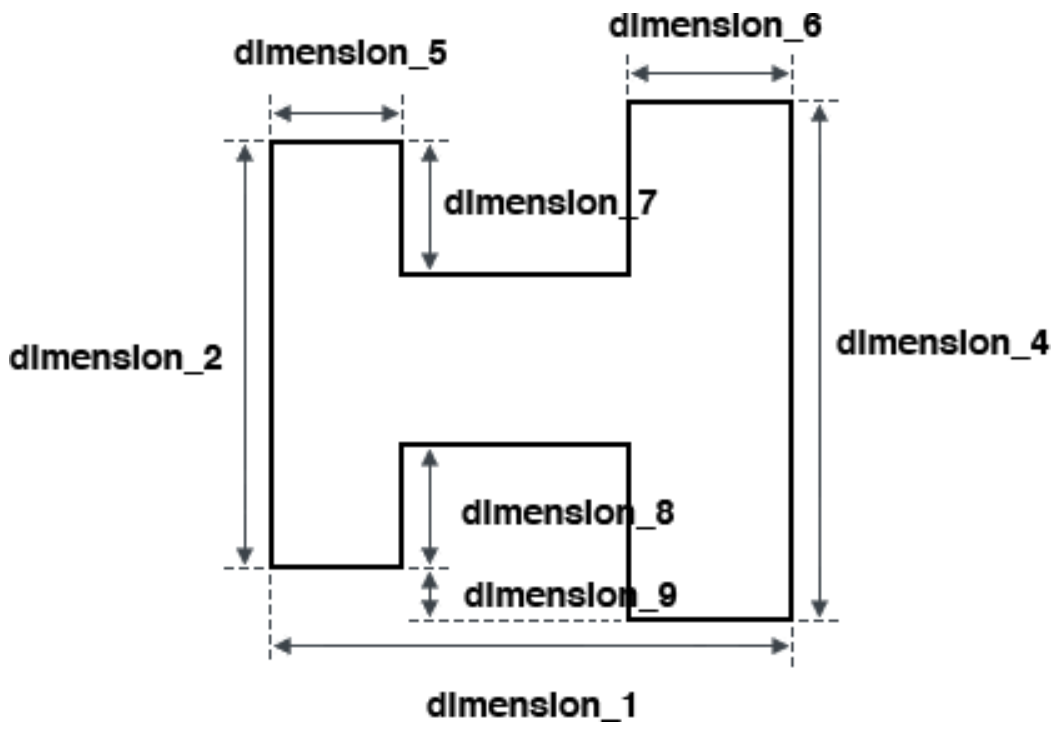

Figure 6. An "H" Shape and Associated Dimensions 


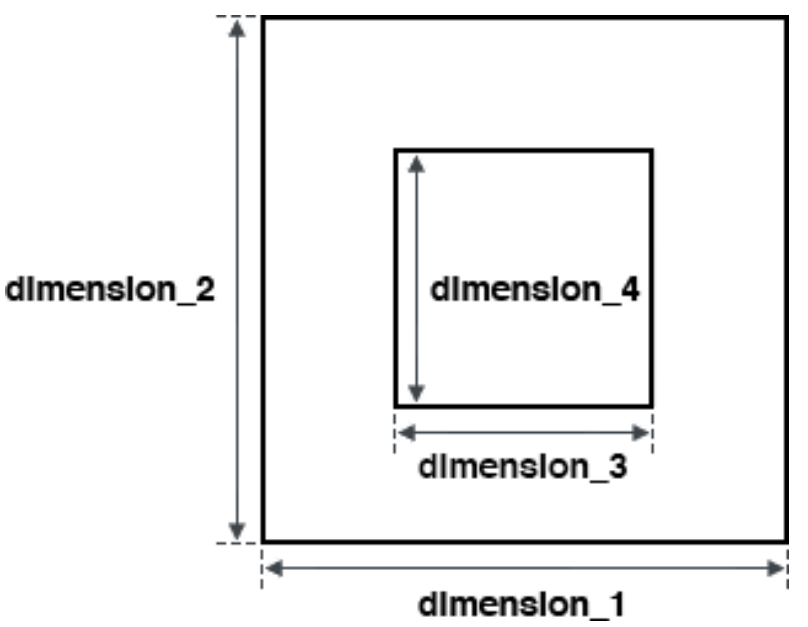

Figure 7. A Courtyard Shape and Associated Dimensions

\subsection{Wall}

The Wall object is a sub-object of a Block. There are as many Walls as there are vertical surfaces for a block, which depends on the shape selected for that particular Block.

Table 4. Wall Object Fields

\begin{tabular}{|c|c|c|}
\hline Field & Type & Description \\
\hline id & Integer & The unique identifier for this wall. \\
\hline wall_type_id & Integer & $\begin{array}{l}\text { ID corresponding to a specific wall type: } \\
\text { 1. Metal panel/curtain wall } \\
\text { 2. Siding on wood frame } \\
\text { 3. Brick/stone on wood frame } \\
\text { 4. Brick/stone on steel frame } \\
\text { 5. Brick/stone on masonry }\end{array}$ \\
\hline r_value & Float & $\begin{array}{l}\text { The R-value of the insulation used in the exterior walls of the parent } \\
\text { block. }\end{array}$ \\
\hline insulation_thickness & Float & $\begin{array}{l}\text { The thickness in inches of the insulation used in the exterior walls of the } \\
\text { parent block. }\end{array}$ \\
\hline u_factor & Float & $\begin{array}{l}\text { The U-factor of the insulation used in the exterior walls of the parent } \\
\text { block. }\end{array}$ \\
\hline created_at & Datetime & $\begin{array}{l}\text { Date and time the envelope was created in the Energy Asset Score } \\
\text { application. }\end{array}$ \\
\hline updated_at & Datetime & $\begin{array}{l}\text { Date and time the envelope was updated in the Energy Asset Score } \\
\text { application. }\end{array}$ \\
\hline window & Object & The Window definitions for this Wall. \\
\hline points & Array & An array of point objects. \\
\hline
\end{tabular}




\subsection{Surface}

A Surface describes one surface of a particular block.

Table 5. Point Object Fields

\begin{tabular}{|c|c|c|}
\hline Field & Type & Description \\
\hline id & Integer & The unique identifier. \\
\hline vertices & String & Describes the $\mathrm{x}, \mathrm{y}$, and $\mathrm{z}$ coordinates for the surface \\
\hline block_id & Integer & The block this surface belongs to \\
\hline edge_fins_only & Boolean & \\
\hline created_at & Datetime & $\begin{array}{l}\text { Date and time the point was created in the Energy Asset } \\
\text { Score application. }\end{array}$ \\
\hline updated_at & Datetime & $\begin{array}{l}\text { Date and time the point was updated in the Energy Asset } \\
\text { Score application. }\end{array}$ \\
\hline edge_offset & Float & \\
\hline fin_depth & Float & \\
\hline fin_distance_between & Float & \\
\hline height & Float & \\
\hline width & Float & \\
\hline light_shelf_distance_from_top & Float & \\
\hline light_shelf_ext_protrusion & Float & \\
\hline light_shelf_int_protrusion & Float & \\
\hline number_of_windows & Integer & \\
\hline overhang_depth & Float & \\
\hline overhang_height_above_window & Float & \\
\hline shading_type_id & Integer & Unique identifier of ShadingType object \\
\hline sill_height & Float & \\
\hline wall_id & Integer & Unique identifier of a Wall object \\
\hline window_id & Integer & Unique identifier of a Window object \\
\hline window_layout_id & Integer & Unique identifier of a WindowLayout object \\
\hline window_width & Float & \\
\hline window_height & Float & \\
\hline window_wall_ratio & Float & $\begin{array}{l}\text { The Window-to-Wall Ratio is the fraction of the above grade } \\
\text { wall area that is covered by fenestration, calculated as the } \\
\text { ratio of the wall fenestration area to the gross above grade } \\
\text { wall area. }\end{array}$ \\
\hline
\end{tabular}

\subsection{Window}

The Window object is a sub-object of the Walls of a Block. There is one Window object per Wall.

Table 6. Window Object Fields

\begin{tabular}{lll}
\hline \multicolumn{1}{c}{ Field } & \multicolumn{1}{c}{ Type } & \multicolumn{1}{c}{ Description } \\
\hline id & Integer & The unique identifier for this window. \\
framing_type_id & Integer & ID corresponding to a specific framing type: \\
& & 1. Metal \\
& & 2. Metal with Thermal Breaks
\end{tabular}




\begin{tabular}{|c|c|c|}
\hline Field & Type & Description \\
\hline & & 3. Wood/Vinyl/Fiberglass \\
\hline glass_type_id & Integer & $\begin{array}{l}\text { ID corresponding to a specific glass type: } \\
\text { 1. Single Pane } \\
\text { 2. Double Pane } \\
\text { 3. Double Pane with Low-E } \\
\text { 4. Triple Pane } \\
\text { 5. Triple Pane with Low-E }\end{array}$ \\
\hline gas_fill_type_id & Integer & $\begin{array}{l}\text { ID corresponding to a specific gas fill type: } \\
\text { 1. Air } \\
\text { 2. Other } \\
\text { 3. None } \\
\text { For single pane windows, the value should be } 3 \text {. }\end{array}$ \\
\hline shading_type_id & Integer & $\begin{array}{l}\text { ID corresponding to a specific shading type: } \\
\text { 1. No Shading } \\
\text { 2. External Overhangs } \\
\text { 3. Vertical Fins } \\
\text { 4. Light Shelves }\end{array}$ \\
\hline operable & Boolean & The value should be true if the windows are operable. \\
\hline window_wall_ratio & Float & $\begin{array}{l}\text { Value between } 0-1.0 .5 \text { would mean that } 50 \% \text { of the exterior } \\
\text { wall area is glazed }\end{array}$ \\
\hline window_layout_id & Integer & $\begin{array}{l}\text { ID corresponding to a specific window layout: } \\
\text { 1. Continuous } \\
\text { 2. Discrete } \\
\text { 3. Various }\end{array}$ \\
\hline overhang_height_above_window & Float & \\
\hline overhang_depth & Float & \\
\hline light_shelf_distance_from_top & Float & \\
\hline light_shelf_ext_protrusion & Float & \\
\hline light_shelf_int_protrusion & Float & \\
\hline fin_depth & Float & \\
\hline edge_fins_only & Boolean & \\
\hline fin_distance_between & Float & \\
\hline edge_offset & Float & \\
\hline sill_height & Float & \\
\hline window_width & Float & \\
\hline window_height & Float & \\
\hline ufactor & Float & \\
\hline shgc & Float & \\
\hline vt & Float & \\
\hline number_of_windows & Integer & \\
\hline created_at & Datetime & $\begin{array}{l}\text { Date and time the window was created in the Energy Asset } \\
\text { Score application. }\end{array}$ \\
\hline updated_at & Datetime & $\begin{array}{l}\text { Date and time the window was updated in the Energy Asset } \\
\text { Score application. }\end{array}$ \\
\hline
\end{tabular}

\subsection{Roof}

The Roof object is a sub-object of a Block. There is one Roof per Block. 
Table 7. Roof Object Fields

\begin{tabular}{|c|c|c|}
\hline Field & Type & Description \\
\hline id & Integer & The unique identifier for this roof. \\
\hline r_value & Float & The R-value of the insulation used in the roof of the parent block. \\
\hline insulation_thickness & Float & $\begin{array}{l}\text { The thickness in inches of the insulation used in the roof of the parent } \\
\text { block. }\end{array}$ \\
\hline u_factor & Float & The U-factor of the insulation used in the roof of the parent block. \\
\hline skylight & Object & The skylight definitions for this roof. \\
\hline created_at & Datetime & $\begin{array}{l}\text { Date and time the roof was created in the Energy Asset Score } \\
\text { application. }\end{array}$ \\
\hline updated_at & Datetime & $\begin{array}{l}\text { Date and time the roof was updated in the Energy Asset Score } \\
\text { application. }\end{array}$ \\
\hline
\end{tabular}

\subsection{Skylight}

The Skylight object is sub-object of a Block. There is one Skylight per Roof.

Table 8. Skylight Object Fields

\begin{tabular}{|c|c|c|}
\hline Field & Type & Description \\
\hline id & Integer & The unique identifier for this skylight. \\
\hline ufactor & Float & \\
\hline shgc & Float & \\
\hline vt & Float & \\
\hline percent_footprint & Float & \\
\hline skylight_layout_id & Integer & $\begin{array}{l}\text { ID corresponding to a specific skylight layout: } \\
\text { 1. Core Only } \\
\text { 2. All Zones }\end{array}$ \\
\hline created_at & Datetime & $\begin{array}{l}\text { Date and time the skylight was created in the Energy Asset Score } \\
\text { application. }\end{array}$ \\
\hline updated_at & Datetime & $\begin{array}{l}\text { Date and time the skylight was updated in the Energy Asset Score } \\
\text { application. }\end{array}$ \\
\hline
\end{tabular}

\subsection{Floor}

The Floor object is a sub-object of a Block. There is one Floor per Block.

Table 9. Floor Object Fields

\begin{tabular}{|c|c|c|}
\hline Field & Type & Description \\
\hline r_value & Float & The R-value of the insulation used in the floor of the parent block. \\
\hline insulation_thickness & Float & $\begin{array}{l}\text { The thickness in inches of the insulation used in the floor of the parent } \\
\text { block. }\end{array}$ \\
\hline u_factor & Float & The U-factor of the insulation used in the floor of the parent block. \\
\hline has_carpet & Boolean & The value should be true of the floor of the parent block is carpeted. \\
\hline created_at & Datetime & $\begin{array}{l}\text { Date and time the floor was updated in the Energy Asset Score } \\
\text { application. }\end{array}$ \\
\hline updated_at & Datetime & Date and time the floor was updated in Energy Asset Score. \\
\hline
\end{tabular}




\subsection{Fixture}

The Fixture object is a sub-object of a Block. Fixtures are contained within the "fixtures" array of a Block, and there must be one or more to simulate the building.

Table 10. Fixture Object Fields

\begin{tabular}{|c|c|c|}
\hline Field & Type & Description \\
\hline id & Integer & The unique identifier for this fixture. \\
\hline mounting_type_id & Integer & $\begin{array}{l}\text { ID corresponding to a specific mounting type: } \\
\text { 1. Recessed } \\
\text { 2. Surface } \\
\text { 3. Pendant }\end{array}$ \\
\hline lamp_type_id & Integer & $\begin{array}{l}\text { ID corresponding to a specific lamp type: } \\
\text { 1. Incandescent/Halogen } \\
\text { 2. Fluorescent } \mathrm{T} 8 \\
\text { 3. Fluorescent T12 } \\
\text { 4. Metal Halide } \\
\text { 5. High-Pressure Sodium } \\
\text { 6. Compact Fluorescent } \\
\text { 7. Fluorescent T5 } \\
\text { 8. Mercury Vapor } \\
\text { 9. LED }\end{array}$ \\
\hline uses_percent_served & Boolean & $\begin{array}{l}\text { Value should be true if specifying the percentage of the floor area } \\
\text { served by this type of fixture, false if specifying the lamp wattage } \\
\text { and total number of fixtures in the block. }\end{array}$ \\
\hline percent_served & Float & Percentage of the block floor area served by this type of fixture. \\
\hline number_of_lamps & Integer & The number of lamps per fixture. \\
\hline number_of_fixtures & Integer & Total number of fixtures of this type in the block. \\
\hline lamp_wattage & Float & \\
\hline has_daylight_controls & Boolean & $\begin{array}{l}\text { Value should be true if daylight sensors are used to control this type } \\
\text { of fixture. }\end{array}$ \\
\hline has_occupancy_controls & Boolean & $\begin{array}{l}\text { Value should be true if occupancy sensors are used to control this } \\
\text { type of fixture. }\end{array}$ \\
\hline created_at & Datetime & $\begin{array}{l}\text { Date and time the fixture was created in the Energy Asset Score } \\
\text { application. }\end{array}$ \\
\hline updated_at & Datetime & $\begin{array}{l}\text { Date and time the fixture was updated in the Energy Asset Score } \\
\text { application. }\end{array}$ \\
\hline
\end{tabular}

\subsection{Air Handler}

The air_handler object is a sub-object of a Building, and linked to one or more blocks.

Table 11. Air_Handler Object Fields

\begin{tabular}{lll}
\hline \multicolumn{1}{c}{ Field } & \multicolumn{2}{c}{ Type } \\
\hline id & Integer & The unique identifier for this HVAC System definition. \\
cooling_air_handler_type_id & Integer & ID corresponding to a specific cooling air_handler_type: \\
& & 1. No Heating
\end{tabular}




\begin{tabular}{|c|c|c|}
\hline Field & Type & Description \\
\hline & & $\begin{array}{l}\text { 2. Central Furnace } \\
\text { 3. Heat Pump } \\
\text { 4. Plant } \\
\text { 5. No Cooling } \\
\text { 6. Central DX }\end{array}$ \\
\hline heating_air_handler_type_id & Integer & $\begin{array}{l}\text { ID corresponding to a specific heating air_handler_type: } \\
\text { 1. No Heating } \\
\text { 2. Central Furnace } \\
\text { 3. Heat Pump } \\
\text { 4. Plant } \\
\text { 5. No Cooling } \\
\text { 6. Central DX }\end{array}$ \\
\hline heating_plant_id & Integer & ID corresponding to a specific heating plant object \\
\hline cooling_plant_id & Integer & ID corresponding to a specific cooling plant object \\
\hline distribution_type_id & Integer & $\begin{array}{l}\text { ID corresponding to a specific air_handler distribution type: } \\
\text { 3. Single Zone } \\
\text { 4. Multi-Zone } \\
\text { 5. Distributed } \\
\text { 6. Looped }\end{array}$ \\
\hline fuel_type_id & Integer & $\begin{array}{l}\text { ID corresponding to a specific fuel type: } \\
\text { 1. Gas } \\
\text { 2. Electricity } \\
\text { 3. Oil }\end{array}$ \\
\hline heating_pieces_of_equipment & Integer & \\
\hline heating_efficiency & Float & \\
\hline heating_equipment_vintage & Integer & The year the installed heating equipment was manufactured. \\
\hline heating_capacity & Float & \\
\hline cooling_type_id & Integer & $\begin{array}{l}\text { ID corresponding to a specific cooling type: } \\
\text { 1. No Cooling } \\
\text { 2. Terminal DX } \\
\text { 3. Central DX Single Zone } \\
\text { 4. Central DX Multi- Zone } \\
\text { 5. Chiller } \\
\text { 6. District }\end{array}$ \\
\hline cooling_efficiency & Float & \\
\hline cooling_pieces_of_equipment & Integer & \\
\hline cooling_capacity & Float & \\
\hline cooling_equipment_vintage & Integer & The year the installed cooling equipment was manufactured. \\
\hline has_economizer & Boolean & \\
\hline sink_source_type_id & Integer & $\begin{array}{l}\text { ID corresponding to a specific sink source type: } \\
\text { 1. Air } \\
\text { 2. Ground }\end{array}$ \\
\hline fan_efficiency & Float & \\
\hline fan_motor_efficiency & Float & \\
\hline fan_control_id & Integer & $\begin{array}{l}\text { 1. Constant volume } \\
\text { 2. Variable air volume }\end{array}$ \\
\hline heating_vintage & Integer & Year of equipment \\
\hline cooling_vintage & Integer & Year of equipment \\
\hline created_at & Datetime & $\begin{array}{l}\text { Date and time the air_handler was created in the Energy Asset } \\
\text { Score application. }\end{array}$ \\
\hline updated_at & Datetime & Date and time the air_handler was updated in the Energy Asset \\
\hline
\end{tabular}




\begin{tabular}{ccc}
\hline Field & Type & Description \\
\hline & Score application \\
\hline
\end{tabular}

\subsection{Zone Equipment}

The zone_equipment object is a sub-object of a Building, and linked to one or more blocks.

Table 12. Zone_Equipment Object Fields

\begin{tabular}{|c|c|c|}
\hline Field & Type & Description \\
\hline id & Integer & The unique identifier for this HVAC System definition. \\
\hline cooling_zone_equipment_type_id & Integer & $\begin{array}{l}\text { ID corresponding to a specific cooling zone_equipment } \\
\text { type: } \\
\text { 1. No Heating } \\
\text { 2. Central Furnace } \\
\text { 3. Heat Pump } \\
\text { 4. Plant } \\
\text { 5. No Cooling } \\
\text { 6. Central DX }\end{array}$ \\
\hline heating_zone_equipment_type_id & Integer & $\begin{array}{l}\text { ID corresponding to a specific heating zone_equipment } \\
\text { type: } \\
\text { 1. No Heating } \\
\text { 2. Central Furnace } \\
\text { 3. Heat Pump } \\
\text { 4. Plant } \\
\text { 5. No Cooling } \\
\text { 6. Central DX }\end{array}$ \\
\hline heating_plant_id & Integer & ID corresponding to a specific heating plant object \\
\hline cooling_plant_id & Integer & ID corresponding to a specific cooling plant object \\
\hline fuel_type_id & Integer & $\begin{array}{l}\text { ID corresponding to a specific fuel type: } \\
\text { 1. Gas } \\
\text { 2. Electricity } \\
\text { 3. Oil }\end{array}$ \\
\hline heating_pieces_of_equipment & Integer & \\
\hline heating_efficiency & Float & \\
\hline heating_equipment_vintage & Integer & $\begin{array}{l}\text { The year the installed heating equipment was } \\
\text { manufactured. }\end{array}$ \\
\hline heating_capacity & Float & \\
\hline cooling_type_id & Integer & $\begin{array}{l}\text { ID corresponding to a specific cooling type: } \\
\text { 1. No Cooling } \\
\text { 2. Terminal DX } \\
\text { 3. Central DX Single Zone } \\
\text { 4. Central DX Multi- Zone } \\
\text { 5. Chiller } \\
\text { 6. District }\end{array}$ \\
\hline cooling_efficiency & Float & \\
\hline cooling_pieces_of_equipment & Integer & \\
\hline cooling_capacity & Float & \\
\hline cooling_equipment_vintage & Integer & $\begin{array}{l}\text { The year the installed cooling equipment was } \\
\text { manufactured. }\end{array}$ \\
\hline has_economizer & Boolean & \\
\hline
\end{tabular}




\begin{tabular}{lll}
\hline \multicolumn{1}{c}{ Field } & \multicolumn{1}{c}{ Type } & \multicolumn{1}{c}{ Description } \\
\hline sink_source_type_id & Integer & ID corresponding to a specific sink source type: \\
& & 1. Air \\
& 2. Ground \\
heating_vintage & Integer & Year of equipment \\
cooling_vintage & Integer & Year of equipment \\
created_at & Datetime & $\begin{array}{l}\text { Date and time the air_handler was created in the Energy } \\
\text { Asset Score application. }\end{array}$ \\
updated_at & Datetime & $\begin{array}{l}\text { Date and time the air_handler was updated in the Energy } \\
\text { Asset Score application }\end{array}$ \\
\hline
\end{tabular}

\subsection{Operation}

The Operation object is a sub-object of a Block. There is only one Operation object per Block.

Table 13. Operation Object Fields

\begin{tabular}{|c|c|c|}
\hline Field & Type & Description \\
\hline id & Integer & The unique identifier for this operations definition. \\
\hline misc_electric_load & Float & \\
\hline misc_gas_load & Float & \\
\hline weekdays_open & Boolean & Value should be true if the block is open on weekdays. \\
\hline weekday_open_time & String & \\
\hline weekday_close_time & String & \\
\hline weekends_open & Boolean & Value should be true if the block is open on weekends. \\
\hline weekend_open_time & String & \\
\hline weekend_close_time & String & \\
\hline total_occupants & Integer & Total number of occupants of the block. \\
\hline setpoint_heating & Integer & \\
\hline created_at & Datetime & $\begin{array}{l}\text { Date and time the operation was created in the Energy Asset Score } \\
\text { application. }\end{array}$ \\
\hline updated_at & Datetime & $\begin{array}{l}\text { Date and time the operation was updated in the Energy Asset Score } \\
\text { application. }\end{array}$ \\
\hline
\end{tabular}

\subsection{Water Heater}

The water_heater object is a sub-object of a Block. There can be zero or more Water Heaters per Block.

Table 14. Water Heater Object Fields

\begin{tabular}{lll}
\hline \multicolumn{1}{c}{ Field } & \multicolumn{1}{c}{ Type } & Description \\
\hline id & Integer & The unique identifier for this water heater. \\
fuel_type_id & Integer & ID corresponding to a specific fuel type: \\
& & 1. Gas \\
& 2. Electricity
\end{tabular}




\begin{tabular}{|c|c|c|}
\hline Field & Type & Description \\
\hline & & 3. Oil \\
\hline distribution_type_id & Integer & $\begin{array}{l}\text { ID corresponding to a specific distribution type: } \\
\text { 1. Distributed } \\
\text { 2. Looped }\end{array}$ \\
\hline uses_heat_pump & Boolean & Value should be true if the water heater uses a heat pump. \\
\hline water_heater_efficiency & Float & \\
\hline tank_insulation_thickness & Float & $\begin{array}{l}\text { The thickness in inches of the insulation used on the water heater } \\
\text { tank. }\end{array}$ \\
\hline tank_insulation_r_value & Float & The R-value of the insulation used on the water heater tank \\
\hline tank_volume & Float & \\
\hline created_at & Datetime & $\begin{array}{l}\text { Date and time the water_heater was created in the Energy Asset } \\
\text { Score application. }\end{array}$ \\
\hline updated_at & Datetime & $\begin{array}{l}\text { Date and time the water_heater was updated in the Energy Asset } \\
\text { Score application. }\end{array}$ \\
\hline
\end{tabular}

\subsection{Plant}

The plant object is a sub-object of Building and Block.

Table 15. Plant Object Fields

\begin{tabular}{|c|c|c|}
\hline Field & Type & Description \\
\hline id & Integer & The unique identifier for this plant. \\
\hline plant_type_id & Integer & $\begin{array}{l}\text { ID corresponding to a specific plant type: } \\
\text { 1. Chiller } \\
\text { 2. District } \\
\text { 3. Boiler }\end{array}$ \\
\hline is_heating & Boolean & True if this is a heating plant \\
\hline Vintage & Integer & \\
\hline pieces_of_equipment & Integer & \\
\hline efficiency & Float & \\
\hline capacity & Float & \\
\hline condenser_type_id & Integer & $\begin{array}{l}\text { ID corresponding to a specific condenser type: } \\
\text { 1. Air } \\
\text { 2. Water }\end{array}$ \\
\hline compressor_type_id & Integer & $\begin{array}{l}\text { ID corresponding to a specific compressor type: } \\
\text { 1. Scroll/Screw } \\
\text { 2. Reciprocating } \\
\text { 3. Centrifugal }\end{array}$ \\
\hline fuel_type_id & Integer & $\begin{array}{l}\text { ID corresponding to a specific fuel type: } \\
\text { 1. Gas } \\
\text { 2. Electricity } \\
\text { 3. Oil }\end{array}$ \\
\hline created_at & Datetime & $\begin{array}{l}\text { Date and time the water_heater was created in the Energy Asset } \\
\text { Score application. }\end{array}$ \\
\hline updated_at & Datetime & $\begin{array}{l}\text { Date and time the water_heater was updated in the Energy Asset } \\
\text { Score application. }\end{array}$ \\
\hline
\end{tabular}




\subsection{Block_Air_Handler}

Manages relationship between an Air_Handler and a Block.

Table 16. Block_Air_Handler Object Fields

\begin{tabular}{|c|c|c|}
\hline Field & Type & Description \\
\hline block_id & Integer & Unique identifier for block \\
\hline air_handler_id & Integer & Unique identifier for air_handler \\
\hline
\end{tabular}

\subsection{Block_Fixture}

Contains all of the fixture info for a particular block.

Table 17. Block_Fixture Object Fields

\begin{tabular}{lll}
\hline \multicolumn{1}{c}{ Field } & \multicolumn{1}{c}{ Type } & Description \\
\hline block_id & Integer & Unique identifier for block \\
fixture_id & Integer & Unique identifier for air_handler \\
uses_percent_served & Boolean & \\
percent_served & Float & \\
number_of_fixtures & Integer & \\
has_daylight_controls & Boolean & \\
has_occupancy_controls & Boolean & \\
\hline
\end{tabular}

\subsection{Block_Water_Heater}

Manages relationship between a Water_Heater and a Block.

Table 18. Block_Water_Heater Object Fields

\begin{tabular}{lll}
\hline \multicolumn{1}{c}{ Field } & \multicolumn{1}{c}{ Type } & \multicolumn{1}{c}{ Description } \\
\hline block_id & Integer & Unique identifier for block \\
water_heater_id & Integer & Unique identifier for water_heater \\
\hline
\end{tabular}

\subsection{Block_Zone_Equipment}

Manages relationship between a Water_Heater and a Block. 
Table 19. Block_Zone_Equipment Object Fields

\begin{tabular}{|c|c|c|}
\hline Field & Type & Description \\
\hline block_id & Integer & Unique identifier for block \\
\hline water_heater_id & Integer & Unique identifier for zone_equipment \\
\hline
\end{tabular}

\subsection{Score}

The Score object is returned after a Building has finished simulation.

Table 20. Score Object Fields

\begin{tabular}{|c|c|c|}
\hline Field & Type & Description \\
\hline current_score & Integer & The current score for the building. \\
\hline current_source_eui & Float & The Source EUI for the current building. \\
\hline potential_score & Integer & $\begin{array}{l}\text { The potential score for the current building if recommended } \\
\text { upgrades were made. }\end{array}$ \\
\hline potential_source_eui & Float & $\begin{array}{l}\text { The potential Source EUI for the current building if recommended } \\
\text { upgrades were made. }\end{array}$ \\
\hline reference_score & Integer & The score for the corresponding reference building. \\
\hline reference_source_eui & Float & The Source EUI for the corresponding reference building. \\
\hline
\end{tabular}




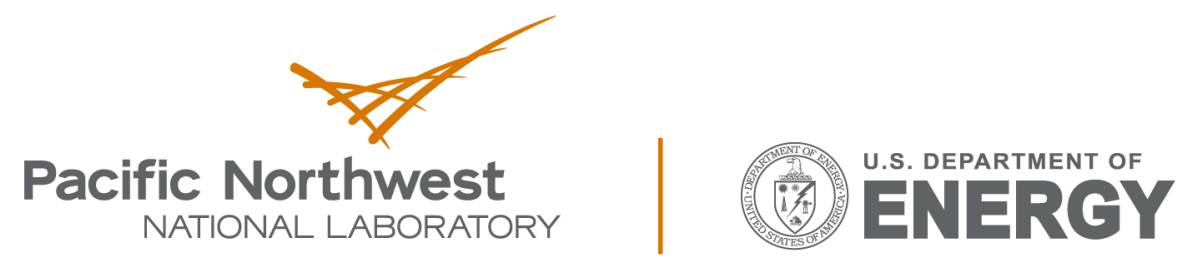

Proudly Operated by Battelle Since 1965

902 Battelle Boulevard

P.O. Box 999

Richland, WA 99352

1-888-375-PNNL (7665)

www.pnnl.gov 